\title{
FIGHTING THE OLIGARCHS: PRESIDENT DUTERTE AND THE ARGUMENT AGAINST ELITE RULE - A PERSPECTIVE FROM THE ACADEME
}

\author{
CHRISTOPHER RYAN MABOLOC*
}

\begin{abstract}
The focus of this study is the radical politics of President Rodrigo Duterte. The leader has clashed with influential businessmen on critical issues. This investigation examines the president's battle against the oligarchy in the country. This research will try show that the rise to power of the first president from Mindanao is a reaction to elite rule. It seeks to reveal that the style of leadership of Duterte is reflective of the historical context that the critics of the president fail to account for. In arguing the case for Duterte's non-conventional approach in overhauling Philippine politics and society, the issues involving some conglomerates in the country are mentioned. In terms of method, the interpretive and analytical approach will be used, citing the available literature and documents to strengthen the article's arguments. The significance of this study has something to do with the idea of good governance. It argues that in the pursuit of a truly democratic society, the foundations of the basic structure must be strengthened. The pragmatic leadership of Duterte is a reflection of the deeper kind of radical change or substantive transformation that is needed to fight elite rule.
\end{abstract}

Keywords: Radical politics; Elite democracy; President Rodrigo Duterte; Philippine oligarchy; Pragmatic leadership

\section{INTRODUCTION}

As the Covid-19 pandemic was unfolding, President Rodrigo Duterte ordered a nationwide lockdown to control the spread of the coronavirus. It caused disruption in the daily lives of ordinary workers, students, and commuters, including the middle class. The new pandemic, which has killed almost a million people around the world, is seen as a threat not only to the way of life of people, but to national security as well. The total costs of the pandemic to the Philippine economy is not yet exactly known, with large malls and small-and-medium enterprises, including the underground businesses of thousands of street vendors, now shut down. The president chose a former military general to lead his Inter-Agency Task Force (IATF) to respond to the pandemic unlike in Western societies in which governments have appointed their top epidemiologists. The positive cases of the coronavirus infections in the country have since risen to 291,789 cases and 5,049 deaths as of September 21, 2020 (DOH, 2020). The president has been lambasted by critics for his stubborn attitude but the leader of a hundred million Filipinos has remained unperturbed.

Duterte is always in his element. While the whole country is fighting the pandemic, the chief executive is also battling another war. The House of Representatives in the Philippines had passed a resolution denying the renewal of the franchise of the giant TV network, ABSCBN (Malindog-Uy 2020). The franchise of the mass media outlet expired in May 2020. Solicitor General Jose Calida, who has filed a quo warranto case at the Philippine Supreme Court against ABS-CBN, has argued that the corporation has violated the terms of its franchise 
(Torres-Tupas 2020). It has been alleged that a foreign investment fund owns Philippine Depository Receipt (PDR) shares in the company (Malindog-Uy 2020). As a broadcasting entity, this is not permitted under Philippines laws. Reports also say that ABS-CBN questionable and unjust tax avoidance schemes (Malindog-Uy 2020). The court later dismissed the case as moot since the franchise has expired. But critics of the president say that closing down the media company means that 11,701 workers would be displaced (Malindog-Uy 2020). However, the president has not changed his mind although it was the Philippine Congress that made the decision. Representative Michael Defensor has said what the president wants during a franchise hearing for ABS-CBN: "We should dismantle the oligarchy in the Philippines." (Esguerra 2020) For Duterte, he will stop at nothing in fighting the country's elite, who, in his mind, are to be blamed for all the problems of the Filipino people. The above is typical of the president who has built a symbolic image of being that father-figure who struggles for the good cause of the ordinary Filipino against the elite's "clandestine and brazen manipulation of state apparatuses to protect and expand their interests; and the elite's employment of various strategies to stay in power." (Labastin 2018).

During the early part of his term, President Duterte identified a prominent businessman as an oligarch that he wanted to topple. The value of the shares of his company, Philweb, plummeted at the stock market due to the pronouncement of the president. Unable to get the franchise for his firm, the owner was forced to sell all his shares in order not to antagonize Duterte. To the mind of the president, the rich businessman was part of the old order who continues to enjoy a privileged position in Philippine society. It matters to ask what the old order is about. The old order refers to powerful oligarchs, landed families, and influential people who dominate the socio-political affairs in Philippine society. When the Spaniards left the country, they bequeathed to the dominant class of Filipinos the rule of the land (Abinales and Amoroso 2005). The perpetuation of this unjust power structure has persisted for more than 100 years. In point of fact, while the absence of a better life for Filipinos may be due to the apparent weakness of the country's institutions, it can argued that a big role has been played by the rent-seeking ways of economic and political opportunists as well, who to this day continue to benefit from the spoils of the country's dark colonial history. When it comes to the Philippine economy, the people can count with their fingers the number of families who dictate the life of the republic. In the capital, for instance, water is controlled by the Ayalas and the Pangilinan group, power distribution was once held by the Lopezes, then by San Miguel Corporation, and right now, by the Pangilinan group. Toll roads and other important infrastructures are owned by San Miguel Corporation and the Pangilinan group, the biggest banks by the SM group and the Ayalas, and real estate by the Ayalas and the SM group. It should be noted though, that the above are legitimate enterprises, and not a product of booty capitalism. But the oligarchy is well-entrenched in the colonial economic system enforced by Spain, whose reason for subjugating the country was actually land and not the introduction of the Christian faith as others would want to believe. (Constantino 1974).

In the 1986 EDSA People Power, Filipinos have restored democracy without bloodshed (Maboloc 2017a). They toppled a dictatorship to put an end to an abusive regime that has plundered the nation's wealth. But it can be said that President Corazon Aquino did not succeed in rebuilding the democratic institutions of the country. Instead of dismantling it, Aquino enabled the oligarchy to assume the control of the economy and to influence the state of affairs in Philippine politics. Instead of returning to the people the Marcos loot and the sequestered assets of the former regime, Aquino instead paved the way for the eventual return of the old order (Hotchcroft and Rocamora 2003). Aquino is an icon of democracy, having defeated the Marcos dictatorship. But it appears that she failed to take advantage of the situation to remove the ills of Philippine politics (Maboloc 2017a). Illicit political bargaining remained even after 
1986. The powers-that-be in the capital controlled the government of Aquino. It was them, in the first place, who helped her remove the former dictator out of Malacanang Palace.

The actions of President Duterte will be described in this study as an example of radicalism using the framework of the Belgian political theorist Chantal Mouffe (1995). Agonistic politics recognizes the reality of conflict as the starting point of politics. The aspect of democracy that pertains to the political involves the type of relationships that is wellcharacterized by the absence of a consensus. This radicalism characterizes the nonconventional approach of President Duterte to governance. Mouffe (1995) believes that the mistake of liberals is to think that people can design a society that is purely rooted in a perfect harmony. Graham Taylor (2010) challenges the idea of homogeneity that is founded in consensus-building which is often used to describe the practice of democracy. The political upheavals in the last decade and the rise of extremism has put to the test the ideals of deliberative democratic rule. In truth, deliberation is only a form of disguise that hides the selfserving interests of the elite who wish to dominate and control the state. Randy David, a sociologist, describes Duterte as a leader who "uses coercive power to intimidate dissenters, critics, skeptics, deviants, and non-cooperative individuals who, in his perception, are not taking him seriously" (David 2016). While Bello (2017) and Curato (2016) are quick to say that Duterte is an autocrat, it is the argument of this paper that his radical approach to governance is needed to fight historical injustice and political domination by those who have dictated the fate of Filipinos since the time of President Manuel Quezon.

\section{SIGNIFICANCE OF THE STUDY}

Students of public and government administration, including policy makers and technocrats, will gain insight into the implications of President Duterte's radical leadership and governance to Philippine democracy, and its relevance to political reform and good governance. Three years after his election into office, President Duterte has caused an unprecedented impact and influence in the socio-economic and political life of the Filipino people. No Filipino president in recent history has figured prominently in headlines around the world like President Duterte. He has shifted alliances away from the United States and the European Union, pivoting to China and Russia in foreign relations, in what he calls an independent foreign policy (Galang 2017). President Duterte has also antagonized the Catholic Church and fought against some of its prominent leaders who are critical of his deadly war on drugs (Esmaquel 2019). With regard to his approach to crime, the president has found adversaries in human rights groups who oppose his violent strategy against criminality (Roth 2019). But the explanation for the said conflicts is the history of domination that has so defined the course of the country's colonial past, one that has created traditional political elites and neglected for a very long time the poor in the periphery, notably the Muslim-Filipinos in the Bangsamoro who have remained impoverished due to the reality of socio-economic exclusion. The research is significant because it will provide the moral and institutional evaluation of the radical style of governance of Duterte, four years into his administration, with the main goal to see if his judgments on important issues hounding the country are justifiable from the perspective of good governance.

\section{METHODOLOGY}

Philosophy does not have a definitive method. Its search for the truth depends on the rigor of critical thinking and reflection. But it is nonetheless concerned with profound questions. While philosophical thought abstracts from the real world, it also seeks for answers to questions that 
have implications to human life. This research is not the typical quantitative research that will rely on data in the evaluation of facts. But this investigation is worth exploring. A philosophical research is a quest to understand the truth. While a qualitative research is not a prominent way of doing studies in Philippine politics, any philosophical attempt at a historical reflection is equally helpful if people are to understand the meaning of their national identity. Throughout this research, the investigator would use textual and interpretive analysis. The research will rely on the available literature and published documents.

\section{RESULTS AND DISCUSSIONS}

\section{Between Deliberative Democracy and Radical Politics}

Deliberative democracy empowers citizens to contribute their ideas in the design of public institutions. The state allows the people to participate in the decision-making process. Central to discursive democracy is the concept of will-formation. The government listens to the people as they voice their concerns and reactions to public issues that matter to them. In his theory of communicative action, Jurgen Habermas (1968) explains that the people or citizens involved in the deliberative process must give their reasons for their arguments in favor of or against any action or proposal by the state. For Habermas, politics is not about finding a universal agreement on every issue. The point is to find the best supported reasoned judgments on matters affecting the public. In this way, there are institutional mechanisms that must prevent the powerful from monopolizing the discussions on public issues and concerns.

In the Philippines, the reality on the ground is that the rich have an influence in the affairs of the state. The poor do not have a strong voice in politics. Even in the crafting of laws, ordinary people do not have the opportunity to freely express themselves. Political dynasties continue to control local politics. Many of the elected officials in the legislature are children of old traditional politicians. Deliberative democracy will not survive in such a situation. Curato (2016), meanwhile, insists that the president must act under the purview of a liberal type of reform. This ignores the historical context that Duterte has been thrown into when he assumed the presidency in 2016. For more than a century, the political elites in the capital control the national agenda (Maboloc 2017b). Mindanao, specifically the Bangsamoro, only received a pittance in resource distribution. Duterte needed to approach politics in a different way. The president knows that he cannot do away with the present political dynamics. Still, he sees that he must use his power to benefit all those who are disadvantaged in Philippine society. With his place in history secured, the president has decentered power in the country and allocated billions to its poorest region, the Bangsamoro, by causing the passage of the Bangsamoro Organic Law (BOL).

The context of structural injustices in Philippine society cannot be ignored. Wataru Kusaka (2017) mentions the perpetual struggle of the members of civil society in the Philippines. But the background culture in the country's basic structure cannot be insulated from the antagonistic class divide that defines Philippine society. While civil society has protested against the atypical attitude of the president, the latter knows that he has the huge support of the masa (people) behind him. In Curato's (2016) assessment, Duterte's popularity is a form of penal populism that is rooted in the president's violent campaign against drugs. She is mistaken. The people of Mindanao, for instance, do not see it that way. Curato (2016) says that the president uses the idea of protecting the good or virtuous against society's criminal elements in justifying his war against drugs. But people in times past actually do not want criminals in their midst. The truth of the matter is the conflict and friction between the president and civil society cannot be reconciled. The reason is political. A consensus in a politically 
polarized country like the Philippines is impossible. People will choose their party loyalties. In this sense, the liberal type of reform, anchored in discursive deliberation, will not work because unjust power structures and elitism in Philippine society must be dismantled first.

Radical democracy, Mouffe (1995) explains, is the "abandonment of the idea of a perfect consensus, of a harmonious collective will, and the acceptance of the permanence of conflicts and antagonisms." There is no way that the president can desire a common interest with oligarchs who only want to exploit the poor in the country. Since the goal of the president is to rectify many years of historical injustices committed against the Filipino people, it is not helpful if President Duterte will seek reconciliation with the oligarchs. The same holds true for drug personalities. In the mind of the president, since drug lords destroy the lives of the youth, there cannot be any compromise with them. Mouffe (1995) believes that "there is no longer a substantive idea of the good life on which rational persons could agree." The President understands that politics is not a walk in the park. It is about power relations and the deployment of effective persuasion.

Mouffe (1995) makes a distinction between "politics" and the "political". The first refers to institutional functions while the latter is about power relations. Politics is about how the state is able to use its mechanisms to achieve particular goals. This includes processes, policies and laws that serve the overall intent of the state apparatus. The political, Taylor (2010) argues, recognizes antagonism in society and so it is crucial to be able to use persuasion. Distinctions are vital in managing the affairs of the state - left and right wing, private and public interest, individual rights and social goods, among other things. Conflict governs the political. Harmony is non-existent. In Duterte's case, this can be observed in his emphasis on the affective sentiments of the people as he pursues the solutions to socio-political problems, including his use of an intimidating language. Critics label Duterte's lack of restraint in his speeches as unpresidential, but many ordinary folks admire his sincerity and the authenticity of his persona. Most Filipinos think that other politicians are simply hypocritical. In fact, Duterte does not differentiate his talks with ordinary people and official functions. He treats them in the same way.

\section{The West Philippine Sea and the Battle against Oligarchs}

Liberal theorists in the country do not like President Duterte. This is quite obvious when they criticized his stand with regard to the West Philippine Sea issue. Critics like Justice Antonio Carpio has stated that the country must make a firm position and should, in this respect, seek the implementation of the decision of the United Nations arbitral court (Tomacruz 2019). The United Nations Convention for the Law of the Sea (UNCLOS) tribunal in The Hague ruled that China has intruded Philippine territory when it built an artificial island in the West Philippine Sea (Tomacruz 2019). Sofia Tomacruz (2020) reports that the president refuses to assert the country's territorial rights, repeating the threat of war with China during his fourth State of the Nation Address. Instead, the Philippine government has sought bilateral discussions to resolve the issue. It is incorrect to say that the country has withdrawn its just and legal claim to the territory. In fact, it has sent its naval force to patrol the area and to protect Filipino fishermen. Carpio (2020), who strongly argues for asserting Philippine sovereignty in the West Philippine Sea, writes:

The July 12, 2016 arbitral Award that invalidated China's nine-dash line claim to waters and resources in the South China Sea (SCS) categorically declared that China never controlled the SCS at any time in history. The Award expressly declared: "The Tribunal is unable to identify any evidence that would suggest that China historically regulated or controlled fishing in the South China Sea, beyond the limits of the territorial sea. With respect to the seabed, the Tribunal does not see any historical activity that could have been restricted or controlled, and correspondingly no basis for a historic right." 
On the issue of the West Philippine Sea, Duterte is a realist when it comes to international relations (Magcamit 2019). He understands the position of the country in the Asia-Pacific region. The president believes that while the United States has signed a mutual defense pact with the Philippines, history suggests that it will only do more harm than good to rely on that agreement. Even the United Nations court has no power to implement the ruling. Instead, the president has used this situation as an opportunity to pivot away from the United States. By welcoming China and opening a new era in the China-Philippines relations, Duterte is sending a strong message to the world that he is someone who will not cower under US influence nor the dictates of domestic power brokers. The UNCLOS tribunal (Tomacruz 2019) may be right in its assertions, but what the critics of the president do not understand is that there is a long history of antagonism between the US and the president. The president does not want to pick any fight with China since he does not trust America.

According to Peter Kreuzer (2020), "Duterte's core message is one of discipline, ironfisted assertion of order, and submission to the top strongman's commands." But this assertion overlooks the important reality that the president was elected not only because of his strong appeal but by the fact that millions of Filipinos are actually fed up by the ineptitude and insensitivity of past leaders who have paid more attention to Manila and simply neglected other parts of the country, especially Mindanao. For this reason, Duterte thrives in the "political". Duterte's use of radicalism in nation-building, especially his will to confront the elite in Philippine society, causes critics to vastly misinterpret the kind of leader that Duterte is. In fact, Duterte's radical approach to politics suggests a new way of doing things in Philippine national politics. Taylor (2010) explains that the real meaning of the public good is not rooted solely in the normative understanding of democracy. Duterte carries a progressive approach that disrupts the state of things, but his "undemocratic ways may be necessary in order to bring about substantive changes in society." (Labastin 2018)

One prominent issue during the early part of the Duterte administration was the case of the tobacco company Mighty Corporation. The Bureau of Internal Revenue (BIR) discovered that the company evaded paying the right taxes. Duterte accused the company of "economic sabotage" (Schnabel 2017). The president gave his warning on national TV against the owners of Mighty Corporation (Ranada 2017). The tax settlement eventually reached 30 billion pesos, the biggest in the country's history, forcing the owners to sell the firm to Japan Tobacco Inc. (JTI) to come up with the cash to pay the BIR (De Vera 2017). It might be recalled, for instance, that the Philippine government at one time charged Lucio Tan of Fortune Tobacco in court, accusing the tycoon of not paying taxes of more than a billion dollars (Gargan 1996). The national government eventually lost the case against the tycoon. In contrast, President Duterte used his strong will to make Mighty Corporation pay without prejudice to the filing of criminal charges later. Against the critics of the president, Benjiemen Labastin (2018) argues that, "Duterte has not become a dictator but he has mastered the subtle and explicit art of intimidation."

During his second year into office, the liabilities of Philippine Airlines (PAL) in using NAIA Terminal II came to the president's attention. The airline company owes the government six billion pesos in rental payments for using the terminal. He warned the company to pay the Philippine government within ten (10) days or else he would shut down the facility (Corrales 2017). As a result, PAL heeded the demand for payment from the Department of Transportation (DOTr). This shows a significant change in terms of political leadership in the country. Had it been another president, a prominent company like PAL would have simply negotiated with the government and if discussions don't end well, the government will be forced to file a case in court that will languish for years. Against PAL, Duterte's kind of leadership makes manifest that "long history of struggle by subordinate classes wherein the desire for social change is expressed outside the bounds of the democratic process" (Labastin 2018). 
In 2019, President Duterte's maverick style came into view in the issue concerning water concessionaires Maynilad and Manila Water. On national TV, the President Duterte accused the two firms of exploiting the public by putting "onerous" provisions in their contracts signed in 1997 (Ranada 2020). The said controversy came into light when Manila Water won its case against the government on water rates hike. The ruling from an international arbitration court stated that the government owes the two water utilities twelve billion pesos. According to Pia Ranada (2020), way back in 1997 when the water shortages were common, the "old contracts contained a rate escalation mechanism designed to ensure the concessionaires would recoup their investments." Duterte found the water rates escalation provision in the contract unacceptable. He then ordered Justice Secretary Menardo Guevarra to craft a revised contract. As a consequence of the president's protests, the country's two firms agreed to renegotiate with the Philippine government.

\section{President Duterte and Elitism in Philippine Society}

The members of the Ilustrado class, according to Michael Cullinane (2003), refers to the educated Filipinos during the colonial period who are children of powerful political clans and influential landed families. In comparison, provincial elites are those who have established their turf in the local scene. In terms of relationship, national politicians promise to bring projects to the provinces whereas provincial political clans are expected to deliver votes to them during elections (Hotchcroft and Rocamora 2003). This relationship defined the elite type of democracy practiced in the country for a century. Benedict Anderson (1998) calls it "cacique democracy." A term that Anderson coined, it refers to the strong powers held by local politicians who act like warlords.

Duterte has positioned himself as anti-elite. He has forged a type of solidarity that is fueled by the devotion of his followers. He has solidified his enviable status as a maverick politician who knows how to get what he wants. More importantly, he symbolizes the struggle against the high culture of the elites. However, his critics would be quick to dismiss the above. They would argue that Duterte is just using intimidation and threats against the enemies of the state (David 2016). Yet, the president's unconventional ways of doing things have produced useful outcomes for the people. It is important to note that the president is simply doing what he thinks is right in terms of giving to ordinary Filipinos the kind of leadership they deserve.

Ilustrado politics is not just about the influence of their parents or political clans. It points to the imbalance of the political states of affairs in Philippine society. The problem is the fact that the Ilustrado class represents the lack of opportunity on the part of poor Filipinos who are equally talented to serve the government, and yet are unable to do so because public office is not open to everyone. Moving away from tradition also means confronting the patrons of the Ilustrado class. This means that Duterte must face off with the old guards in the Philippines. More than anything else, it is symbolic of the fact that the president wanted to confront the powers that be in business. He has also warned PLDT and Globe to improve internet speed in the country or else he will cause the cancelling of their franchises (Salaverria 2020). He used the same strategy against Maynilad and Manila Water (Corrales 2019). It was effective. The president said that the oligarchy have benefited from the extractive nature of the Philippine economy. The president often emphasizes the "common good" in his speeches. To him, it is public interest that is paramount. It is for this reason that he has said that he is willing to sacrifice his life, his honor, and the presidency for the sake of the people.

Although Duterte speaks against the oligarchy, having chastised the owners of Maynilad and Manila Water for being too greedy, he has been accused of embracing a new elite. Richard Heydarian (2019) thinks that the president targets businesses identified with the opposition. Critics say that Duterte allowed the emergence of a new oligarch. In particular, the emergence 
of DITO Telecommunity is a case in point. It is the third telco in country that has been recently granted a franchise by the Philippine Congress. It is backed by the state-owned China Telecom. DITO is expected to compete against the telecom duopoly of Smart and Globe. Whether the rise of the telco company is beneficial or an affliction to the legacy of the president will ultimately depend on the socio-economic impact of the business. In short, it is premature to say that the president is paving the way for a breed of new oligarchs.

Idealists dream of a well-ordered society. In that world, what people need are taken care of. There is equality among citizens and opportunities are available for everyone. People can make choices and they determine for themselves the kind of life they so desire. But Duterte is not an idealist. He does not see the world that way. The president sees social conflict as the starting point of politics. For this reason, Duterte's leadership style means that he would take a different course of action. Today, Duterte is in the middle of a great challenge to his presidency. When it comes to his approach to the pandemic, the president is aware that this is about protecting the country. He understands that the coronavirus knows no moral, social, or economic boundaries. In what is to be called the new normal, a good friend may no longer want to shake hands, students and workers need to adapt to new technologies, and people might push themselves to the end of the food line because they simply do not want their family to go hungry. Duterte knows that the pandemic is a war that knows no political color. It is leadership that will matter if the country must get back on its feet.

The mistake that critics make is thinking that strong leadership is only reserved to dictators. A leader who is determined to protect the welfare of his people also needs to be strong. In the case of Duterte's radical leadership, he acts like a father-figure. There are historical facts to prove that this style of dealing with the people was employed by former revolutionaries during the American period. Orlino Ochosa (2005) writes that the likes of Miguel Malvar, Macario Sakay, and Julian Montalan treated town folks in a way that shows the character of a benevolent or a caring leader whose main goal or interest is to serve his people. The type of leadership that Duterte possesses - strong and unconventional - is reflective of his personality. He is a man who minces no words. He means what he says and does what he says. That is his true character, a character that sometimes ignites the cultural divide between the Bisaya-speaking South and the Tagalog-speaking North. Duterte knows how to capitalize on this. He realizes that the Bisaya are all behind him and for this reason, he continues to rally the cause and frustrations of the Bis-dak (Bisayang dako).

It is important, however, that in the remainder of his term, Duterte must pay more attention to the other problems of the country. The long list should include improving the difficult living conditions in Metro Manila by decongesting the capital, the pursuit of federalism in the area of constitutional reform, causing the passage of an anti-dynasty bill to end the perpetuation of clans and political dynasties, and eradicating corruption in government agencies. While critics would zero in on his war on drugs, the narrative goes far beyond that. The important aspect of Duterte's style of governance is unfamiliar to deliberative types of reform. Duterte's pragmatic leadership is a matter of common sense. Leadership to him, indeed, is about how to get things done. Duterte does not mind the criticisms. He is a man who is not afraid to destroy his enemies. In this regard, his brand of leadership is not about the virtuous state. Duterte acts more in the same manner as the Roman politician who is concerned about the well-being of the people and yet is also aware of the true dynamics of power. This is not to say that he owes something to anyone. But the point of the matter is that he understands the meaning of a debt of gratitude in politics by saying that anything like it must never be forgotten. 


\section{Beyond Radicalism and Pragmatic Leadership}

In the local dialect, the rich is called "maykaya." It is a combination of two terms, "may' means "possession" and "kaya", which means "capable." The rich or "maykaya" then refers to the sense of possessing something that makes one capable. But this sense of capability is not about freedom or human capability as espoused by the Indian economist and philosopher Amartya Sen. "Maykaya" as understood by Filipinos refers to material power. In contrast, the poor are called "mahirap." The root word is "hirap" which means "difficult" in English. The word is descriptive of the life of the poor. Life is difficult for the poor because they possess nothing. The poor is also connected to the term "masa," which was used by Duterte in his past program, "Gikan sa Masa." The term "masa," which is "mass" or "the masses" in English, is political in terms of context. The "masa" is that sector that the president identifies himself with. Being the son of a former governor of the undivided Davao, the president was not born poor. The use of the term in this regard has a different connotation.

The critics of the president seem to equate his use of the term "masa" to populism. This is not the sentiment of the people whom the former mayor has served. In fact, he has transformed Davao City into a progressive center of commerce and education in Mindanao. In the Philippines, Filipinos are enamored by a populist style of governance in which they think that a politician is the solution to every problem. This is symptomatic of the old patronage system that has come as a consequence of the country's dark colonial past (Ileto 1979). As a result, the Philippines suffers from a great divide in which the affluent are expected to live an honorable life while the poor are to remain poor unless the same will find connections that may elevate one's life-situation.

The problem of the Philippines has something to do with good governance (Brillantes and Fernandez 2011). There is simply too much politics in the country. The Philippines needs clear and substantive types of reform. People do not know what to do in terms of finding the effective solutions to social or economic problems because the government institutions that are supposed to help them are not functioning well. For example, there is over-dependence on blood relationship rather than effective governance (Lara 2015). The clannish character of local politics can mean that extending good government service to the public becomes a political debt in the mind of the people instead of being a mechanism to serve the public. It is important to change this mindset. Without real reform, the gains from strong leadership can only be temporary.

Duterte is a good leader but we must not forget the serious need of building the foundations of a truly democratic society. For example, some government officials at the local level arrogate themselves by showing off their luxurious life (Tamayo 2011). The political will of the president is important because without it, it would not be possible to cause change in Philippine society due to its colonial context. Every Filipino needs to embrace a sense of civic duty. Duterte's leadership is a vital part of the equation. It matters to have a good leader so that people will realize the value of discipline in a society where the same is lacking. But to have discipline means that every citizen puts aside his interest and commit to the realization of the public good. People have to recognize their obligation to state by helping ensure public accountability, the respect for the rule of law, and greater transparency.

The pragmatic approach of Duterte is misconstrued by his critics as the arrogance of power. The president has to simply show that no one can wield absolute power. Duterte makes it clear that his mandate comes from the people. Duterte is a unique politician. But it is crucial to a democratic society to realize that good governance begins with a common vision. This means that the people and their leaders are the integral components to the spirit of solidarity. The unity of the people can only be founded in the singular belief that each person will have an equal chance in achieving the good life. This implies that opportunities are available to 
everyone. In such a way, society becomes truly inclusive.

Labastin (2018) says that "any direction towards authoritarianism must be criticized at all cost," but he also explains that "any effort to challenge and shaken the ruling order are all the more important." The contestation that Duterte has created and all the tension within the basic structure of the country is hoped to "bring the creative spirit of the Filipinos buried by years of colonization, domination and oppression" (Labastin 2018). Part of the quest for greater freedom of the people is the dismantling of unjust structures and elitist systems that dominate their lives. Democracy is founded in the respect of the rights of every citizen. It is never about power. Rather, it considers the value of every human person on the basis of fair policies, equal opportunities, and the equitable distribution of wealth.

\section{CONCLUSION}

This study has examined the leadership style of President Duterte. The investigation explains how and why Duterte acts in the way that he does as the leader of the nation. This can be traced to the reality of conflict and the social divide between the elite and the poor. Duterte's leadership style is understandable given the fact that he seeks to confront the powers that be in society. In fact, Duterte is seen as a pragmatist in terms of his leadership. People have faith in him because he gets things done, unlike his predecessor who lacked political will. President Duterte came to national significance at a time when the poor are resigned to their fate. People have come to a point where they no longer trust those in government. The president sees his kind of governance as the struggle of the masses. The masses, for obvious reasons, look up to him as a messiah. But there is a perceived bias with the way his critics and the Western media portrays the former mayor. This prejudice can be traced to a narrative that serves nothing but an orthodoxy. The orthodoxy refers to that caricature in which Duterte is portrayed as a dictator. To his ardent critics, strong leadership is equal to authoritarianism.

However, the high trust rating of the chief executive also means that Filipinos are already fed up with elite politics in the country. For this reason, they see the value in making a wager on the kind of governance that President Duterte inspires. Yet, it is crucial to recognize that a mature democracy thrives in strong institutions, transparent policies, and inclusivity. While the president recognizes the value of the foregoing, it is critical to strengthen the basic structure in the country to make the outcomes of a leader's political will sustainable. Hence, this study ends with a claim that democracy cannot thrive on the basis of traits of one man. It is about enduring principles that will serve as the supreme foundation of a just society. If institutions function well, then people would have no need for strong leaders. Power is a very dangerous thing. Left unto the care of bad leaders, it can destroy the values of society and the ideals of authentic democracy.

\section{REFERENCES}

Abinales, P. and Amoroso, D. 2005. State and Society in the Philippines. Lanham: Rowman and Littlefield.

Anderson, B. 1998. "Cacique Democracy in the Philippines: Origins and Dreams." In New Left Review, 3-31.

Bello, W. 2017. "Rodrigo Duterte: A Fascist Original." In A Duterte Reader. Edited by Nicole Curato. Quezon City: Ateneo de Manila University Press.

Brillantes, A. and Fernandez, M. 2011. "Restoring Trust and Building Integrity in Government. In International Public Management Review 12 (2): 55-80. 
Carpio, A. 2020. "China is not in possession of WPS." In Philippine Daily Inquirer. https://opinion.inquirer.net/132441/china-is-not-in-possession-of-wps.

Constantino, R. 1974. The Philippines: A Past Revisited. Manila: Tala Publications.

Cullinane, M. 2003. Ilustrado Politics. Quezon City: Ateneo de Manila University Press.

Curato, N. 2016. "Politics of Anxiety, Politics of Hope: Penal Populism and Duterte's Rise to Power." In Journal of Current Southeast Asian Affairs 3: 99-109.

Corrales, N. 2017. "Duterte to Lucio Tan: Pay PAL arrears or I'll shut down NAIA Terminal 2." In Philippine Daily Inquirer. https://business.inquirer.net/237572/rodrigo-duterte-philippine-airlines-lucio-tannavigational-fees.

Corrales, N. 2019. "Duterte warns: I will seize Maynilad, Manila Water on Onerous deals." In Philippine Daily Inquirer.

https://newsinfo.inquirer.net/1200193/duterte-warns-i-will-seize-maynilad-manilawater-over-onerous-deals.

David, R. 2016. "Dutertismo." In Philippine Daily Inquirer. https://opinion.inquirer.net/94530/dutertismo\#ixzz5MnDSO63X.

David, R. 2018. "The Duterte Method." In Philippine Daily Inquirer. [Internet] https://opinion.inquirer.net/112636/the-duterte-method

De Vera, B. 2017. "Global tobacco firm acquires Mighty Corporation.” In Philippine Daily Inquirer.

https://business.inquirer.net/236465/global-tobacco-firm-acquires-mighty-corp.

Department of Health. 2020. Nationwide Cases Data for Covid-19 [Internet] https://www.doh.gov.ph/2019-

nCoV?fbclid=IwAR2tUXfSRNH1 ADujCc7FA1dzFJcM8D9TS5mPH6xdBUDkHTdw gxEKouN9P1k.

Esguerra, C. 2020. "Cayetano hits media partisanship ahead of ABS-CBN franchise vote." In ABS-CBN News.

https://news.abs-cbn.com/news/07/09/20/cayetano-hits-media-partisanship-ahead-ofabs-cbn-franchise-vote.

Esmaquel, P. 2019. "Duterte versus the Church: Do the Times call for Catholic Vote?" In Rappler. https://thediplomat.com/2017/04/us-china-and-dutertes-independent-foreign-policy/.

Galang, M. 2017. "US, China, and Duterte's Independent Foreign Policy." In The Diplomat. https://thediplomat.com/2017/04/us-china-and-dutertes-independent-foreign-policy/.

Gargan, E. 1996. "An Asian Billionaire tries to fly by the New Rules." In The New York Times. https://www.nytimes.com/1996/09/15/business/an-asian-billionaire-tries-to-fly-by-thenew-rules.html.

Habermas, J. 1968. Knowledge and Human Interest. Suhrkamp Verlag: Frankfurt am Main.

Heydarian, R. 2019. "Duterte replacing old elite with new in Philippines." In Asia Times. https://asiatimes.com/2019/12/duterte-replacing-old-elite-with-new-in-philippines/.

Hotchcroft, P. and Rocamora, J. 2003. "Strong Demands and Weak Institutions." Journal of East Asian Studies Volume 3 (2): 259-292.

Ileto, R. 1979. Pasyon and Revolution. Quezon City: Ateneo de Manila Press.

Kreuzer, P. 2020 A Patron-Strongman who delivers: Explaining enduring public support for President Duterte in the Philippines. Frankfurt: Peace Research Institute Frankfurt.

Kusaka, W. 2017 Moral Politics in the Philippines. Singapore: National University of Singapore Press.

Labastin, B. 2018 "Two Faces of Dutertismo: Two Faces of Democracy in the Philippines." In Social Ethics Society Journal of Applied Philosophy 4 (3): 31-54. 
Lara, F. 2015. Insurgents, Clans, and States: Political Legitimacy and Resurgent Conflict. Quezon City: Ateneo de Manila Press.

Linantud, J. 2016. "Tracking Philippine Elections, Strongman Politics, and Rodrigo Duterte." In Center of Excellence for Public Policy and Good Governance Magazine 4: 17-21.

Maboloc, C.R. 2017a. "The Problem of Philippine Democracy." In Philippine Daily Inquirer. https://opinion.inquirer.net/106326/problem-philippine-democracy.

Maboloc, C.R. 2017b. "Situating the Mindanao Agenda in the Radical Politics of President Duterte." In Iqra: Journal of Al Qalam Institute 4: 3-24.

Magcamit, M. 2019. "The Duterte Method: A neoclassical realist guide to a small power's foreign policy and strategic behavior in the Asia-Pacific." In Asian Journal of Comparative Politics 5 (2): 416-436.

Malindog-Uy, A. 2020. "Why did Congress deny ABS-CBN a franchise?" In The Asean Post. https://theaseanpost.com/article/why-did-congress-deny-abs-cbn-franchise.

Mouffe, C. 1995. "Liberalism and Modern Democracy." Democracy and Possessive Individualism, ed. Joseph Carens. New York: SUNY Press.

Ochosa, O. 1995. Bandoleros: Outlawed Guerillas of the Philippine-American War. Manila: New Day Publishers

Ranada, P. 2017. "Duterte orders arrest of Mighty Corporation owner." In Rappler. [Internet] https://rappler.com/business/sona-2017-duterte-accepts-mighty-corp-tax-settlement.

Ranada, P. 2020. "Duterte to Ayalas, Pangilinan: Agree to fair water contracts, I'll forget cases." In Rappler. https://rappler.com/nation/duterte-tells-ayalas-pangilinan-agree-fair-water-contracts.

Roth, K. 2019. "World Report - Philippines." In Human Rights Watch. [Internet] https://www.hrw.org/world-report/2019/country-chapters/philippines.

Schnabel, C. 2017. “Duterte accepts Mighty Corporation's 25 billion peso tax settlement.” In Rappler.

https://rappler.com/business/sona-2017-duterte-accepts-mighty-corp-tax-settlement.

Salaverria, L. 2020. "Duterte warns Smart, Globe of expropriation." In Philippine Daily Inquirer.

https://newsinfo.inquirer.net/1313097/duterte-warns-smart-globe-of-expropriation.

Tamayo, R. 2011. “Arrogant Public Officials." In Philippine Daily Inquirer. [Internet] https://opinion.inquirer.net/8223/arrogant-public-officials.

Taylor, G. 2010. "The End of the Nation State: The Disarticulation of Power and Identity." The New Political Sociology. London: Palgrave Macmillan.

Teehankee, J. 2016. "Duterte's Resurgent Nationalism in the Philippines: A Discursive Institutionalist Analysis." In Journal of Current Southeast Asian Affairs Volume 35 (3): 69-89.

Tomacruz, S. 2019. "Carpio on West Philippine Sea: Every Filipinos duty to defend PH Territory." In Rappler. [Internet] https://rappler.com/nation/carpio-west-philippine-seaevery-filipinos-duty-defend-territory

Tomacruz, S. 2020. "Duterte repeats threat of war with China; refuses to assert West PH Sea rights." In Rappler.

https://rappler.com/nation/duterte-repeats-threat-war-china-refuses-assert-westphilippine-sea-rights.

Torres-Tupas, T. 2020. "SolGen insists SC should forfeit ABS-CBN franchise." In Philippine Daily Inquirer.

https://newsinfo.inquirer.net/1234330/solgen-insist-sc-should-forfeit-abs-cbn-franchise

United Nations-Habitat. 2003. The Challenge of Slums. United Nations Human Settlements Programme. London. 
CHRISTOPHER RYAN MABOLOC

Ateneo de Davao University

Roxas Ave, Poblacion District, Davao City,

8000 Davao del Sur, Philippines

*Corresponding author: ryanmaboloc75@yahoo.com 